\title{
Influence of Different Plant Spacings on Vegetative Growth and Yield of Red Cabbage (Brassica oleracea var. capitata f. rubra)
}

\author{
S. Manasa , L. Mukunda Lakshmi, Syed Sadarunnisa and T. Rajasekharam \\ College of Horticulture, Anantharajupeta, Dr. Y.S.R. Horticultural University, \\ Andhra Pradesh, India \\ *Corresponding author
}

\section{A B S T R A C T}

\begin{tabular}{|l|}
\hline Ke y w or d s \\
$\begin{array}{l}\text { Red cabbage, Spacing, } \\
\text { Growth, Yield. }\end{array}$ \\
\hline Article Info \\
\hline $\begin{array}{l}\text { Accepted: } \\
\text { 15 September } 2017 \\
\text { Available Online: } \\
10 \text { November } 2017\end{array}$ \\
\hline
\end{tabular}

A field study was conducted at AICRP on Citrus, Citrus Research Station, Tirupati, Andhra Pradesh during the year 2017 under Dr. Y.S.R. Horticultural University, to find out the Influence of different plant densities on vegetative growth and yield of red cabbage (Brassica oleracea var. capitata f. rubra) cv. Red Jewel. Three different spacings were taken viz., $45 \times 45 \mathrm{~cm}, 60 \times 45 \mathrm{~cm}$ and 60x60 $\mathrm{cm}$. The experimental variables measured were vegetative characters (plant height, plant spread and number of leaves at 30,60 DAT and at harvest along with number of days for head initiation and harvest) and yield (yield per plot and marketable yield). Plant spread, number of leaves, days for head initiation and days to harvest generally increased as the plant spacing increased, whereas, plant height, yield per plot and marketable yield were increased with a decrease in plant spacing.

\section{Introduction}

Red cabbage (Brassica oleracea var. capitata f. rubra) is an important fancy and highly nutritive exotic vegetable. It belongs to the family Brassicaceae, having chromosome number $2 \mathrm{x}=2 \mathrm{n}=18$. It comes under the subgroup rubra of cabbage (Brassica oleracea var. capitata L.). It is a biennial but grown as annual for its characteristic purple or red edible heads. It is used as salad, boiled vegetable, cooked in curries, used in pickling as well as dehydrated vegetable. Red cabbage is known to possess medicinal properties. It has an anticancer property due to the presence of indole-3-carbinol. It is a rich source of carotene, proteins $(0.35 \%)$, fats $(0.25 \%)$, minerals like calcium (3.56\%), phosphorus (19.90\%), potassium, sulphur etc. and vitamins viz., $\mathrm{A}, \mathrm{B}_{1}, \mathrm{~B}_{2}$ and $\mathrm{C}$. In India, its cultivation is negligible but now gaining popularity with Indian growers for the last few years due to its high nutritive value and increased tourist influx.

In India, cabbage including red cabbage is cultivated in an area of 388 thousand ha producing 8755 thousand MT (Anonymous, 2015-16). In Andhra Pradesh, the crops are cultivated in 5.43 thousand ha with a production of 81.45 thousand tonnes. Apart from India, red cabbage can be found 
throughout Northern Europe, America, and parts of China. Since this crop has been introduced recently in Andhra Pradesh, there is a need to standardize the package of practices to suit the local conditions. Among various factors that contribute towards the attainment of potential yield in red cabbage, spacing is of prime consideration. Maintenance of optimum plant population per unit area plays an important role on yield. Too high or too low plant densities per unit area reduce the crop yields. In recent years, there has been a growing interest in the use of narrow rows as well as narrow plant spacing for the production of cabbage. By changing inter and intra row spacings, several workers reported higher yield in crops like broccoli (Agarkar et al., 2010), tomato (Singh, 2004) and cabbage (Mahesh Kumar and Rawat, 2002).

In spite of its greater importance in terms of returns, no systematic research work has been carried out to standardize the suitable agrotechniques for successful cultivation of red cabbage in Andhra Pradesh.

Therefore, it is essential to find out the optimum plant densities for vegetative growth and yield maximization of red cabbage (Brassica oleracea var. capitata f. rubra) in Andhra Pradesh.

\section{Materials and Methods}

The present investigation entitled "Influence of different plant spacings on vegetative growth and yield of red cabbage (Brassica oleracea var. capitata f. rubra)" was executed at AICRP on Citrus, Citrus Research Station, Tirupati, Andhra Pradesh during rabi, 2017 under Dr. YSR Horticultural University. The experiment was laid out in a factorial randomized block design with three replications. The experiment was carried out with the variety Red Jewel. The experimental area was divided into plots of $3.5 \mathrm{~m} \times 3.5 \mathrm{~m}$ size. Red cabbage seedlings were transplanted at a spacing of $45 \times 45 \mathrm{~cm}, 60 \times 45 \mathrm{~cm}$ and 60 $\times 60 \mathrm{~cm}$ as per the treatments. To raise the crop recommended package of practices were followed. The various parameters were recorded from five randomly selected tagged plants viz., plant height, plant spread, number of leaves, days taken for head initiation, days to harvest, yield per plot and marketable yield. The data was subjected to statistical analysis as per method suggested by Panse and Sukhatme (1967).

\section{Results and Discussion}

The results obtained from the present investigation as well as relevant discussion have been summarized under following heads:

\section{Plant height}

The result of the experiment revealed significant difference among treatments with regard to plant height at 30,60 DAT and at harvest. At 30, 60 DAT and at final harvest, the tallest plants $(19.62,24.52$ and $30.69 \mathrm{~cm}$, respectively) were recorded at closer spacing $(45 \times 45 \mathrm{~cm})$ followed by medium spacing $(18.00,22.71$ and $30.05 \mathrm{~cm}$, respectively) while the shortest plants $(17.80,20.05$ and $28.75 \mathrm{~cm}$, respectively) were found from wider spacing $(60 \times 60 \mathrm{~cm})$ (Table 1$)$.

It was observed that maximum plant height was recorded with the closer plant spacing of $45 \times 45 \mathrm{~cm}$ at different sampling occasions. Increased plant density coupled with shallow root system limits the availability of space for lateral growth.

This leads to the competition between the plants for light and nutrients, resulting in increased plant height. These findings were in agreement with Rastogi et al., (1987) in 
radish, Khurana et al., (1990) in cauliflower and Hill (2000) in Chinese cabbage.

\section{Leaf number per plant}

Data in Table 1 revealed that the wider the plant spacing the higher was the leaf number. Maximum number of leaves per plant at 30, 60 DAT and at final harvest (19.56, 26.51 and 33.10 , respectively) was obtained at the widest spacing of $60 \mathrm{~cm} \times 60 \mathrm{~cm}$ and minimum number of leaves per plant (16.43, 23.94 and 30.09 , respectively) was found at the lowest spacing of $45 \times 45 \mathrm{~cm}$. This might be due to lesser competition for nutrients and light amongst the plants with lower plant density. Hence in wider spacing due to the availability of more space and light, the crop might have produced more number of leaves per plant. These results were in conformity with the results of Hill (2000) in Chinese cabbage, Singh (2005) in cauliflower and Agarkar et al., (2010) in broccoli.

\section{Plant spread}

Effect of plant spacing on spread of plant was found to be significant at different DAT (at 30, 60 DAT and at harvest). Maximum spread of plant at 30,60 DAT and at harvest (22.70,
51.85 and $66.46 \mathrm{~cm}$, respectively) was obtained from $60 \mathrm{~cm} \times 60 \mathrm{~cm}$ followed by 60 $\times 45 \mathrm{~cm}$ and the lowest (18.62, 44.18 and $51.95 \mathrm{~cm}$, respectively) from $45 \times 45 \mathrm{~cm}$. These results can be attributed to fact that, in wider spacing the individual plant gets plenty of light and more nutrients in comparison to closer spacing. The results of present findings were in agreement with the findings of Sharma and Chaudhary (1996) in cauliflower and Purushottam (2001) in cabbage.

\section{Number of days for head initiation}

Number of days from transplanting to head initiation was not significantly varied among different plant densities. However, wider spaced plants required maximum days for head initiation (50.44) whereas minimum number of days (47.73) for closer spaced plants. Higher photosynthesis and dry matter assimilation due to higher number of leaves coupled with higher availability of nutrients leads to vegetative growth for longer period and as such the reproductive phase was delayed. Similar results were reported by Sharma et al., (1995) in broccoli, Sharma and Koul (2004) in leek and Chatterjee (2006) in cauliflower.

Table.1 Effect of different plant spacings on plant height, number of leaves and plant spread in red cabbage

\begin{tabular}{|c|ccc|ccc|ccc|}
\hline \multirow{2}{*}{ Treatments } & \multicolumn{3}{|c|}{ Plant height $(\mathbf{c m})$} & \multicolumn{3}{c|}{ Number of leaves } & \multicolumn{3}{c|}{ Plant spread } \\
\cline { 2 - 10 } & 30 & 60 & At & 30 & 60 & At & 30 & 60 & At \\
& DAT & DAT & harvest & DAT & DAT & harvest & DAT & DAT & harvest \\
\hline $45 \times 45 \mathrm{~cm}$ & 19.62 & 24.52 & 30.69 & 16.43 & 23.94 & 30.09 & 18.62 & 44.18 & 51.95 \\
$60 \times 45 \mathrm{~cm}$ & 18.00 & 22.71 & 30.05 & 18.59 & 24.93 & 32.12 & 20.71 & 47.92 & 59.70 \\
$60 \times 60 \mathrm{~cm}$ & 17.80 & 20.05 & 28.75 & 19.56 & 26.51 & 33.10 & 22.70 & 51.85 & 66.46 \\
$\mathbf{S . E m} \pm$ & 0.154 & 0.119 & 0.350 & 0.155 & 0.113 & 0.100 & 0.125 & 0.170 & 0.154 \\
C.D(P=0.05) & 0.462 & 0.356 & 1.051 & 0.466 & 0.340 & 0.301 & 0.375 & 0.512 & 0.464 \\
\hline
\end{tabular}


Table.2 Effect of plant spacings on days for head initiation, days to harvest, yield per plot and marketable yield in red cabbage

\begin{tabular}{|c|c|c|c|c|}
\hline Treatments & $\begin{array}{c}\text { Days for head } \\
\text { initiation }\end{array}$ & Days to harvest & Yield per plot & $\begin{array}{c}\text { Marketable } \\
\text { yield }\end{array}$ \\
\hline $45 \times 45 \mathrm{~cm}$ & 47.73 & 82.55 & 23.80 & 183.69 \\
\hline $60 \times 45 \mathrm{~cm}$ & 48.55 & 83.33 & 19.87 & 153.29 \\
\hline $60 \times 60 \mathrm{~cm}$ & 50.44 & 85.55 & 16.23 & 125.21 \\
\hline S.Em \pm & 0.732 & 0.409 & 0.077 & 0.783 \\
\hline C.D(P=0.05) & N.S.* & 1.227 & 0.232 & 2.350 \\
\hline
\end{tabular}

\section{Days to harvest}

Number of days to harvest was significantly influenced by different plant densities (Table 2). The treatment $45 \times 45 \mathrm{~cm}$ took lowest number of days to harvest (82.55), which was statistically identical with $60 \times 45 \mathrm{~cm}(83.33)$, while at $60 \times 60 \mathrm{~cm}(85.55)$ maximum number of days were required for harvesting. Closely spaced plants experience heavy competition among themselves for available nutrients which induces poor synthesis and utilization of accumulates reduced photosynthetic efficiency. This results in limited vegetative growth and short vegetative phase that leads to an early commencement of reproductive phase. Similar results were reported by Sharma et al., (1995) in broccoli, Sharma and Koul (2004) in leek and Chatterjee (2006) in cauliflower.

\section{Yield per plot}

Perusal of the data in Table 2 indicates highly significant results for yield per plot. Planting density of $45 \times 45 \mathrm{~cm}$ gave the highest yield (23.80 kg/plot) which was statistically similar to medium plant density $(19.87 \mathrm{~kg} / \mathrm{plot})$. The lowest yield (16.23 kg/plot) was recorded with lower plant density. The maximum yield per plot was found superior at higher plant density which was possibly due to more number of plants per unit area; higher ground covers of leaf area resulted in higher light interception and hence, higher assimilate production. Similar results have been reported by Sharma and Chaudhary (1996) in cauliflower and Agarwal et al., (2007) in broccoli.

\section{Marketable yield}

Marketable yield of red cabbage was significantly influenced by the plant spacing. The maximum marketable yield (183.69 q/ha) was obtained from the spacing of $45 \times 45 \mathrm{~cm}$ followed by the medium plant density (153.29 $\mathrm{q} / \mathrm{ha}$ ) while, minimum yield (125.21 q/ha) was recorded with lower plant density.

This is due to the reality that as plant spacing decreases, total plant population increases and this in turn contributes to increase in total head yield. The current result is in agreement with works of different authors. Hossain et al., (2011) recorded that closer spacing $(60 \mathrm{x}$ $40 \mathrm{~cm})$ produced the maximum yield (18.8 t/ha), which was statistically similar when spaced at $60 \times 50 \mathrm{~cm}(17.6 \mathrm{t} / \mathrm{ha})$ and lowest yield (16 t/ha) was from wider $(60 \times 60 \mathrm{~cm})$ spacing in broccoli. "Captain" broccoli hybrid recorded the highest yield $(10.8 \mathrm{t} / \mathrm{ha})$ at highest plant density $(60 \times 50 \mathrm{~cm})$ due to more number of plants $/ \mathrm{m}^{2}$, whereas at $70 \times 50$ $\mathrm{cm}$ spacing higher values of curd weight and morphometric traits were recorded (Fabeket al., 2011). According to Bhangre et al., (2011) planting of broccoli at a spacing of 45 x $30 \mathrm{~cm}$ and $60 \times 60 \mathrm{~cm}$ recorded higher (77.08 q/ha) and lower head yield (50.38 
q/ha), respectively. Similar results have been reported by Agarwal et al., (2007) in broccoli.

The study was conducted to investigate the best plant spacing for highest yield. The spacing used in the study showed significant variation among the different treatment. From the investigation it can be concluded that, at 30, 60 DAT and at final harvest, the tallest plants (19.62, 24.52 and $30.69 \mathrm{~cm}$, respectively) were recorded at closer spacing $(45 \times 45 \mathrm{~cm})$ and the shortest plants (17.80, 20.05 and $28.75 \mathrm{~cm}$ ) were found from low density planting $(60 \times 60 \mathrm{~cm})$. Highest number of leaves (19.56, 26.51 and 33.10, at 30, 60 DAT and at final harvest, respectively) and plant spread $(22.70,51.85$ and $66.46 \mathrm{~cm}$, at 30, 60 DAT and at final harvest, respectively) were noticed at $60 \times 60 \mathrm{~cm}$ and the lowest were recorded at $45 \times 45 \mathrm{~cm}$. High density plants took less number of days for both head initiation and days to harvest. But, highest yield per plot $(23.80 \mathrm{~kg})$ and marketable yield (183.69 q/ha) were recorded at high plating density $(45 \times 45 \mathrm{~cm})$.

\section{References}

Agarkar, U.R, Dadmal, K.D, Nikas, N.S. and Piwlatkar, G.K. 2010.Effect of nitrogen levels and spacing on growth and yield of broccoli (Brassica oleracea var. italica L.). Green Farming.1(5): 477 479.

Agarwal, A, Gupta, S. and Ahmed, Z. 2007. Nitrogen nutrition and plant density influencing marketable head yield of broccoli in cold arid desert of Ladakh. Acta Horticulture.756: 299 - 307.

Anonymous, 2015-16. National Horticulture Mission, Government of India.

Bhangre, K.K, Sonawane, P.C. and Warade, S.D. 2011.Effect of different varieties and spacing on growth and yield parameters of broccoli (Brassica oleracea L. var. italica) under Pune conditions. Asian Journal of Horticulture. 6 (1): 74-76.

Chatterjee, R. 2006. Effect of transplanting dates and spacing on seed yield and quality of cauliflower (Brassica oleracea var. botrytis L.) cv. Pusa Early Synthetic. Seed Research.34 (1): 104 106.

Fabek, S, Toth, N, Benko, B and Peic, I. 2011. The effect of plant density on morphological traits and yield of broccoli.GlasnikZastiteBilja. 34 (1): 2229.

Hill, T.R. 2000.Effect of plant spacing and nitrogenous fertilizers on the yield of Chinese cabbage (Brassica campestris sp. pekinensis). Australian J. Experimental Agri. 30 (3): 437 - 439.

Hossain, M.F, Ara, N, Uddin, M.R, Dey, S and Islam, M.R. 2011.Effect of time of sowing and plant spacing on broccoli production. Tropical Agricultural Research and Extension. 14 (4): 90-92.

Khurana, D.S, Harjit Singh, Jarnail Singh and Cheema, D.S. 1990. Effect of N, P and plant population on yield and its components in cauliflower. Indian journal of Horticulture.47 (1): 70 - 74.

Mahesh Kumar and Rawat, T.S. 2002. Effect of nitrogen and spacing on the quality and yield of cabbage (Brassica oleracea L. var. capitata). Agric. Sci. Digest. 22 (2): $90-92$.

Panse, M. and Sukhatme, K. 1985.Statistical methods for agriculture workers. Indian Council of Agriculture Research Publications.48-67.

Purushottam, P.K. 2001. Plant spacing: a key husbandry practice for rainy season cabbage production. Nepal Agricultural Research Journal. 4 \& 5: 48 - 55.

Rastogi, K.B, Sharma, P.P. and Korla, B.N. 1987. Effect of different levels of nitrogen and spacing on seed yield of radish (Raphanus sativus L.). Vegetable Science.14: 105 - 109. 
Sharma, D.K, Chaudhary, D.R. and Raj Narayan. 1995. Effects of dates of planting and plant density on growth of curd and seed yield in sprouting broccoli (Brassica oleracea var. italica) cv. Green Head. South Indian Horticulture.43 (1- 2): 59-61.

Sharma, D.K. and Chaudhary, D.R. 1996. Time of sowing and plant density on growth and curd yield in early cauliflower (Brassica oleracea L. var. botrytis) cv. Early Kunwari. Vegetable Science. 23 (2): 141 - 144.

Sharma, D.K. and Koul, B.L. 2004. Effect of dates of planting and spacing on growth and yield in leek (Allium porrum L.) cv. Musselburgh. Vegetable Science. 31 (2): $199-200$.

Singh, A.K. 2004.Effect of nitrogen and phosphorus on growth and curd yield of cauliflower var. Snowball- 16 under cold arid region of Ladakh. Haryana $J$. of Horticultural Sciences.33 (1/2): 127 $-129$.

Singh, R.V. 2005. Response of late cauliflower to plant spacing nitrogen and phosphorus fertilization. Journal of Research.17: 223 - 226.

\section{How to cite this article:}

Manasa, S., L. Mukunda Lakshmi, Syed Sadarunnisa and Rajasekharam, T. Influence of Different Plant Spacings on Vegetative Growth and Yield of Red Cabbage (Brassica oleracea var. capitata f. rubra). 2017. Int.J.Curr.Microbiol.App.Sci. 6(11): 1695-1700. doi: https://doi.org/10.20546/ijcmas.2017.611.204 